Research article

\title{
MORPHOLOGICAL CHARACTERISTICS AND EXPRESSION OF ESTROGEN AND PROGESTERONE RECEPTORS IN THE CANINE ENDOMETRIUM DURING THE ESTRUS CYCLE, CYSTIC ENDOMETRIAL HYPERPLASIA AND PYOMETRA
}

\author{
MARINKOVIĆ Darko ${ }^{1 *}$, ANIČIĆ Milan", VAKANJAC Slobodanka², \\ NEDIĆ Svetlana², MAGAŠ Vladimir ${ }^{2}$ \\ ${ }^{1}$ Department of Pathology, Faculty of Veterinary Medicine, University of Belgrade, Bul. Oslobodenja \\ 18, Belgrade, Serbia; ${ }^{2}$ Department of Reproduction, Fertility and Artificial Insemination, Faculty of \\ Veterinary Medicine, University of Belgrade, Bul. Oslobođenja 18, Belgrade, Serbia
}

(Received 03 July, Accepted 06 September 2018)

The estrus cycle of bitches is divided into four phases: proestrus, estrus, diestrus and anestrus, during which different morphological changes, and also cyclic changes of estrogen and progesterone receptors are present. Several pathological changes can be differentiated on the endometrium, but one of these is the most important - cystic endometrial hyperplasia, which frequently develops into pyometra.

The aim of the present study was to describe morphological characteristics, and expression of estrogen and progesterone receptors on the endometrium of mixedbreed bitches during the different phases of the estrus cycle, cystic endometrial hyperplasia and pyometra.

The uterus and ovaries of 36 mixed breed bitches in different phases of the estrus cycle and also with cystic endometrial hyperplasia (CEH) and chronic purulent endometritis - pyometra were examined macroscopically, histopathologically, and immunohistochemically for estrogen receptors (ER) and progesterone receptors (PR).

During proestrus uterine cells showed a weak reaction for both estrogen and progesterone receptors, but during estrus a large number of uterine cells showed a strong reaction on estrogen receptors and moderate reaction on progesterone receptors. On the contrary, during diestrus the scores for the estrogen receptors decreased, while the progesterone receptors level increased - uterine cells expressed strong reaction for progesterone receptors, and moderate reaction for estrogen receptors.

Uterine cells in cystic endometrial hyperplasia expressed a strong reaction for estrogen receptors, and moderate reaction for progesterone receptors, but on the other hand the uterine cells in the uterus with pyometra expressed a moderate to strong reaction for progesterone receptors, and a weak reaction for estrogen receptors.

\footnotetext{
*Corresponding author: e-mail: darko@vet.bg.ac.rs
} 
In further investigations it would be interesting to perform quantitative analysis for both estrogen and progesterone receptors during different phases of the estrus cycle and also in the uterus with cystic endometrial hyperplasia and pyometra.

Key words: bitches, uterus, cystic endometrial hyperplasia, pyometra, estrogen receptors, progesterone receptors

\section{INTRODUCTION}

Estrus is a crucial physiological process for the procreation of all mammal species. Bitches are sexually mature by 6 to 8 month of age, and their estrus cycle is diestral with the mating seasons in spring and in autumn. The estrus cycle of bitches is divided into four phases: proestrus, estrus, diestrus and anestrus. Proestrus is the follicular phase, which lasts for 5 to 10 days while the luteal phase consists of the estrus and diestrus. Estrus lasts for 5 to 15 days and diestrus lasts for 50 to 80 days. The long nonseasonal period between cycles is called anestrus and lasts for 80 to 240 days [1,2]. Reproductive organs - ovaries, salpinx, uterus, cervix and vagina, in bitches develop different morphological changes during the estrus cycle. The most prominent changes are on the ovaries and on the endometrium [1-4]. Also, phases of the estrus cycle are characterized by cyclic changes of estrogen and progesterone receptor concentrations within individual cells in the bitch uterus which can be demonstrated using an immunohistochemical technique [5-9].

Several pathological changes can be differentiated on the endometrium, but one of these is the most important - cystic endometrial hyperplasia, which frequently develops into pyometra. Cystic endometrial hyperplasia $(\mathrm{CEH})$ is a pathological condition common in bitches which is characterized by cystic distension of endometrial glands, and can involve a single or a few glands, but sometimes the entire endometrial surface is involved. The endometrium is usually thickened with variably dilated glands notable on the cross-section of the uterine wall [10-12]. The importance of cystic endometrial hyperplasia is in its ability to progress to a more important disease of the uterus pyometra. Pyometra is a chronic suppurative infection of the endometrium which is characterized by accumulation of pus in the uterine lumen, and most cases of pyometra in the bitch are associated with cystic endometrial hyperplasia [12-15]. Pyometra in bitches is occurring mostly due to hormonal disbalance. This disease usually occurs during diestrus, which is characterized by high levels of progesterone, which promote endometrial proliferation and glandular activity, and also suppress contractions of the myometrium and leukocyte inhibition in the uterus. Beside the role of progesterone, estrogen is also important in the etiopathogenesis of the pyometra because high levels of this hormone during proestrus and estrus can increase uterine sensitivity to progesterone in the following stages of the estrus cycle [8].

The aim of the present study was to describe morphological characteristics on the endometrium of the mixed-breed bitches during the different phases of the estrus cycle, cystic endometrial hyperplasia and chronic purulent endometritis - pyometra. 
Also, to immunohistochemically determine expression of the sex steroid receptors in the canine endometrium in the described estrus phases and pathological conditions cystic endometrial hyperplasia and chronic purulent endometritis - pyometra.

This knowledge can be used as a reference for the research of functional morphology and uterine pathology of the bitch.

\section{MATERIAL AND METHODS}

During the annual spaying programme six hundred mixed breed bitches were spayed. All bitches were submitted to ovariohysterectomy and after macroscopic evaluation tissue samples of the uterus and ovaries were taken for histopathological evaluation. The uterus and ovaries of 36 bitches at different phases of the estrus cycle -6 at each phase based upon anamnestic, clinical data and vaginal cytology (anestrus, proestrus, estrus and diestrus), and also with $\mathrm{CEH}$ (6 bitches) and chronic purulent endometritis - pyometra (6 bitches) were submitted to macroscopical and histopathological examination. Samples of the uterus were fixed in $10 \%$ buffered formalin. After standard processing in an automated tissue processor, tissue samples were embedded in paraffin blocks and $5 \mu \mathrm{m}$ thick sections were stained with hematoxylin and eosin (HE).

The phase of the estrus cycle was once more confirmed by macroscopical and histopathological findings on the ovaries and uteri. Also, uteri with $\mathrm{CEH}$ and chronic purulent endometritis - pyometra were also evaluated based on the histopathological findings. Chosen tissue samples of the uterus from different phases of the estrus cycle (anestrus, proestrus, estrus and diestrus), uteri with $\mathrm{CEH}$ and chronic purulent endometritis - pyometra were submitted to immunohistochemical detection for estrogen and progesterone receptors.

\section{Immunohistological protocol}

Immunohistochemical staining of the canine uterine tissue samples for the purpose of detection of the expression of the estrogen receptors protein (ER) and progesterone receptors (PR) was performed. Indirect three step streptavidin-biotin detecting method $\left(\mathrm{LSAB}^{+} / \mathrm{HRP}\right.$ kit, DAKO) where streptavidin was marked with horseradish peroxidase.

Formalin-fixed paraffin embedded tissue samples were cut to $5 \mu \mathrm{m}$ sections and the three-step indirect immunohistochemical (IHC) technique was performed. Tissue sections were deparaffinazed in xylol and rehydrated through a series of alcohols of decreasing concentrations $(100 \%, 96 \%, 70 \%)$. Antigen retrieval was achieved by heating the tissue sections in a microwave oven at $560 \mathrm{~W}$ for 21 minutes in a commercial citrate buffer pH 6.0 (Target Retrival Solution, Code No. S 1700, DAKO). The sections were treated with methanol containing $0.3 \%$ hydrogen peroxide for 10 minutes at room temperature in order to inactivate endogenous peroxidase. Then 
the tissue sections were incubated with primary antibodies (ER mouse monoclonal antibody, NCL-L-ER-6F11, Novocastra) 1:100 diluted and (PR mouse monoclonal antibody, NCL-PGR-312, Novocastra) 1:100 diluted over night in a humid chamber at room temperature. After that samples were incubated with biotinized anti-mouse and anti rabbit imunoglobulins for 30 minutes at room temperature. In the next step the sections were treated with horseradish peroxidase streptavidin conjugate for 30 minutes at room temperature. The immunoreaction was visualized with $\mathrm{DAB}+$ kit (3,3'-diaminobenzidine tetrahydrochloride, DAKO, K3468). For dissolving the primary antisera the commercial dilutant (Cat. No. SO809, DAKO) and for rinsing during immunohistochemical staining $0.01 \mathrm{M}$ phosphate buffer $\mathrm{pH} 7.4$ was used. Sections were counterstained with Mayer's hematoxylin. Aqueous medium glycergel (Aquatex-OC 261903, Merck, Germany) was used on the stained sections for mounting. Canine uterus and ovaries in estrus which were formerly confirmed positive for ER and PR were used as positive controls. The intensity of positive staining was scored according to three categories: + - weak, ++ - moderate, +++ - strong [6].

The results of histochemical and immunohistochemical staining were analyzed by light microscope (BX51, Olympus Optical, Japan). Pictures were taken with Olympus Color View III ${ }^{\circledR}$ digital camera.

\section{RESULTS}

\section{Histopathological findings on the endometrium during the estrus cycle, cystic endometrial hyperplasia (CEH) and pyometra}

Anestrus phase of the estrus cycle was characterized by hardly notable crypts of the epithelium (Fig. 1a). During proestrus the epithelial layer consisted of cuboidal cells, and gradual growth and differentiation of the crypts were notable (Fig. 1d). The dominant finding during the estrus was endometrial hyperemia, and growth, differentiation and dilatation of the glandular, mucus producing cells (Fig. 2a). The finding on the endometrium during diestrus phase was characterized by well-developed mucus producing endometrial crypt glands, and also accumulation of lipid droplets in the epithelial endometrial cells (FEEC - foamy endometrial epithelial cells) (Fig. 2d).

The uterus with cystic endometrial hyperplasia $(\mathrm{CEH})$ was characterized by hyperplastic endometrium which formed different sized cysts without associated inflammatory cellular infiltration (Fig. 3a).

Chronic purulent endometritis - pyometra was characterized by endometrial hyperplasia, with enlarged prismatic endometrial cells, sometimes with pycnotic nuclei. Hyperplastic endometrium sometimes formed cysts and sometimes papilliform proliferations, and often erosions and hemorrhages were also recorded. The dominant characteristic of pyometra was the inflammation of the endometrium which was characterized by a large amount of neutrophil granulocytes, plasma cells and macrophages present in the uterine lumen, endometrium - endometrial cysts and diffusely in the epithelial and stromal part of the endometrium (Fig. 3d). 

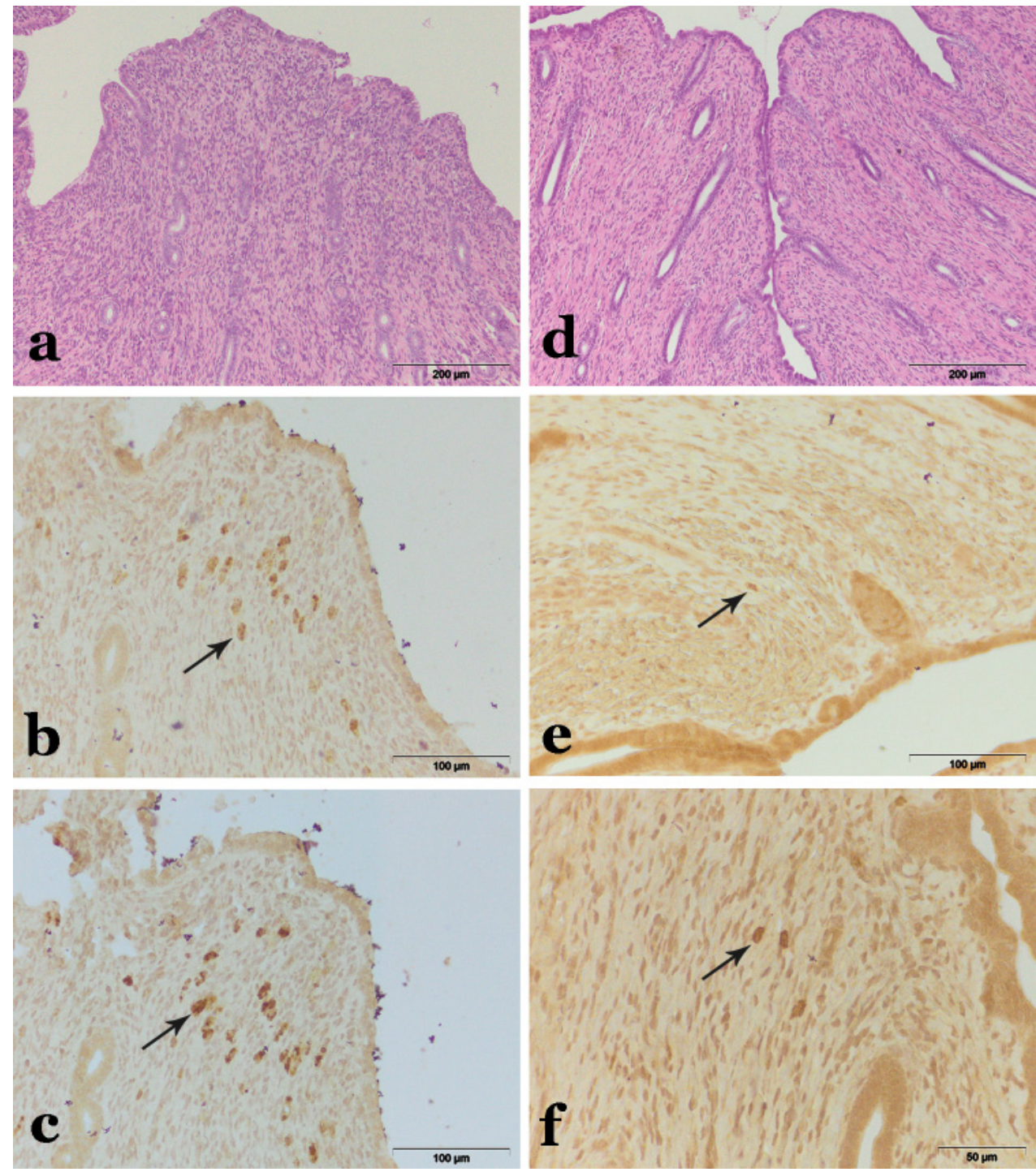

Figure 1. Histopathologic appearance of the canine endometrium, and the expression of the estrogen and progesteron receptors in anestrus - a) $\mathrm{HE}$; b) $\mathrm{LSAB}^{+} \mathrm{ER}$ (arrow); c) $\mathrm{LSAB}^{+} \mathrm{PR}$ (arrow); and proestrus - d) $\mathrm{HE}$; e) $\mathrm{LSAB}^{+} \mathrm{ER}$ (arrow); f) $\mathrm{LSAB}^{+} \mathrm{PR}$ (arrow)

\section{Immunohistochemical findings - expression of the estrogen and progesterone receptors on the endometrium during the estrus cycle, cystic endometrial hyperplasia (CEH) and pyometra}

The anestrus phase was characterized by uterine cells - mostly stromal which showed a moderate reaction of both estrogen and progesterone receptors (Fig. 1b and 1c). During proestrus uterine cells showed a weak reaction of both estrogen and progesterone receptors, in the stromal and glandular epithelial cells (Fig. 1e and 1f). During estrus 
a large number of uterine cells showed a strong reaction on estrogen receptors and a moderate reaction on progesterone receptors (Fig. $2 b$ and 2c). During diestrus the scores for the estrogen receptors decreased, while progesterone receptor levels increased - uterine cells expressed a highly positive (strong) reaction on progesterone receptors, and a moderate reaction on estrogen receptors (Fig. 2e and 2f).
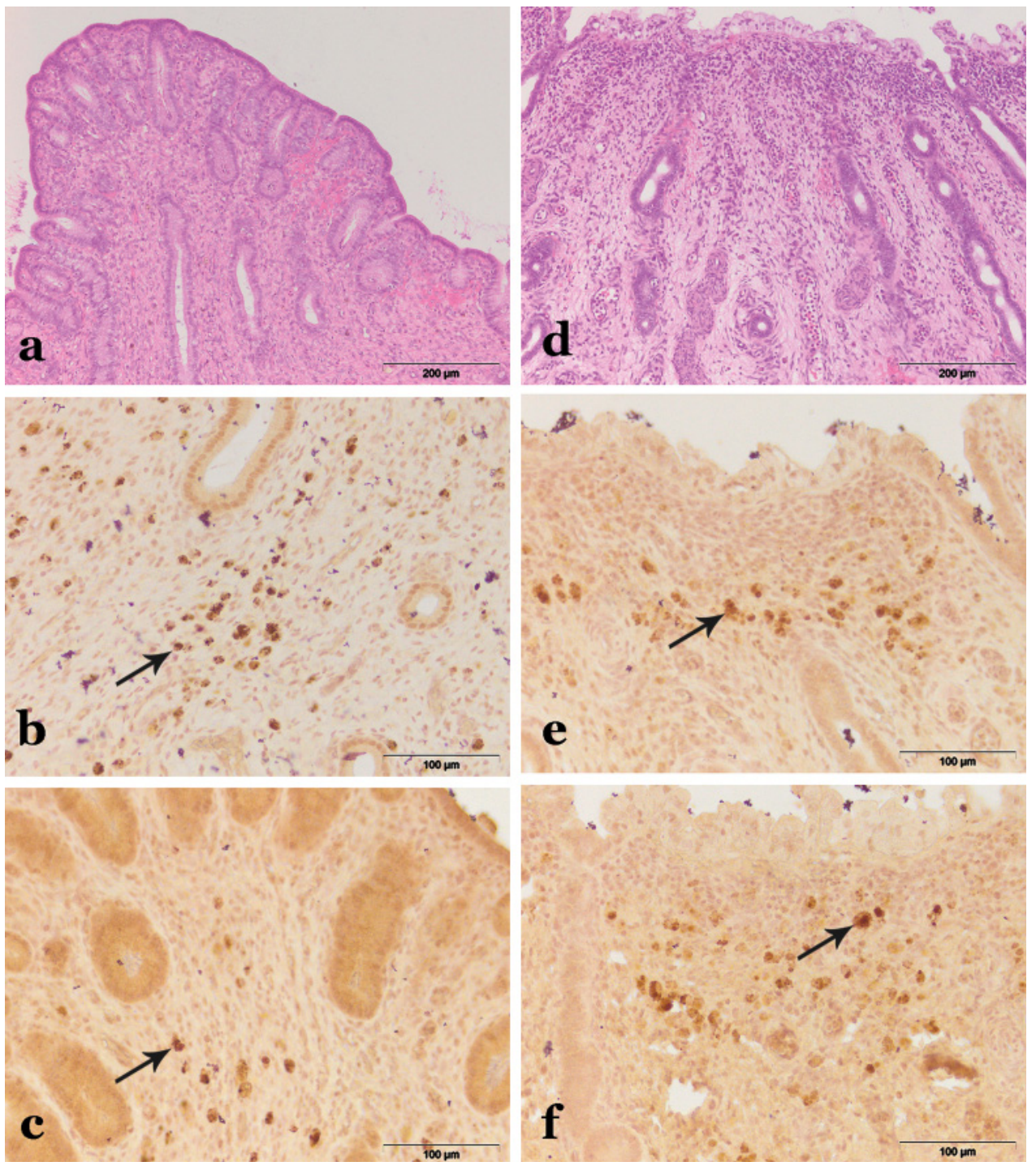

Figure 2. Histopathologic appearance of the canine endometrium, and the expression of the estrogen and progesteron receptors in estrus - a) $\mathrm{HE}$; b) $\mathrm{LSAB}^{+} \mathrm{ER}$ (arrow); c) $\mathrm{LSAB}^{+} \mathrm{PR}$ (arrow); and diestrus - d) HE; e) $\mathrm{LSAB}^{+} \mathrm{ER}$ (arrow); f) $\mathrm{LSAB}^{+} \mathrm{PR}$ (arrow) 
The uterine cells in the uterus with cystic endometrial hyperplasia $(\mathrm{CEH})$ expressed a strong reaction on estrogen receptors, and moderate reaction on progesterone receptors (Fig. 3b and 3c).

The uterine cells in the uterus with pyometra expressed a moderate to strong reaction on progesterone receptors, and a weak reaction on estrogen receptors (Fig. 3e and 3f).
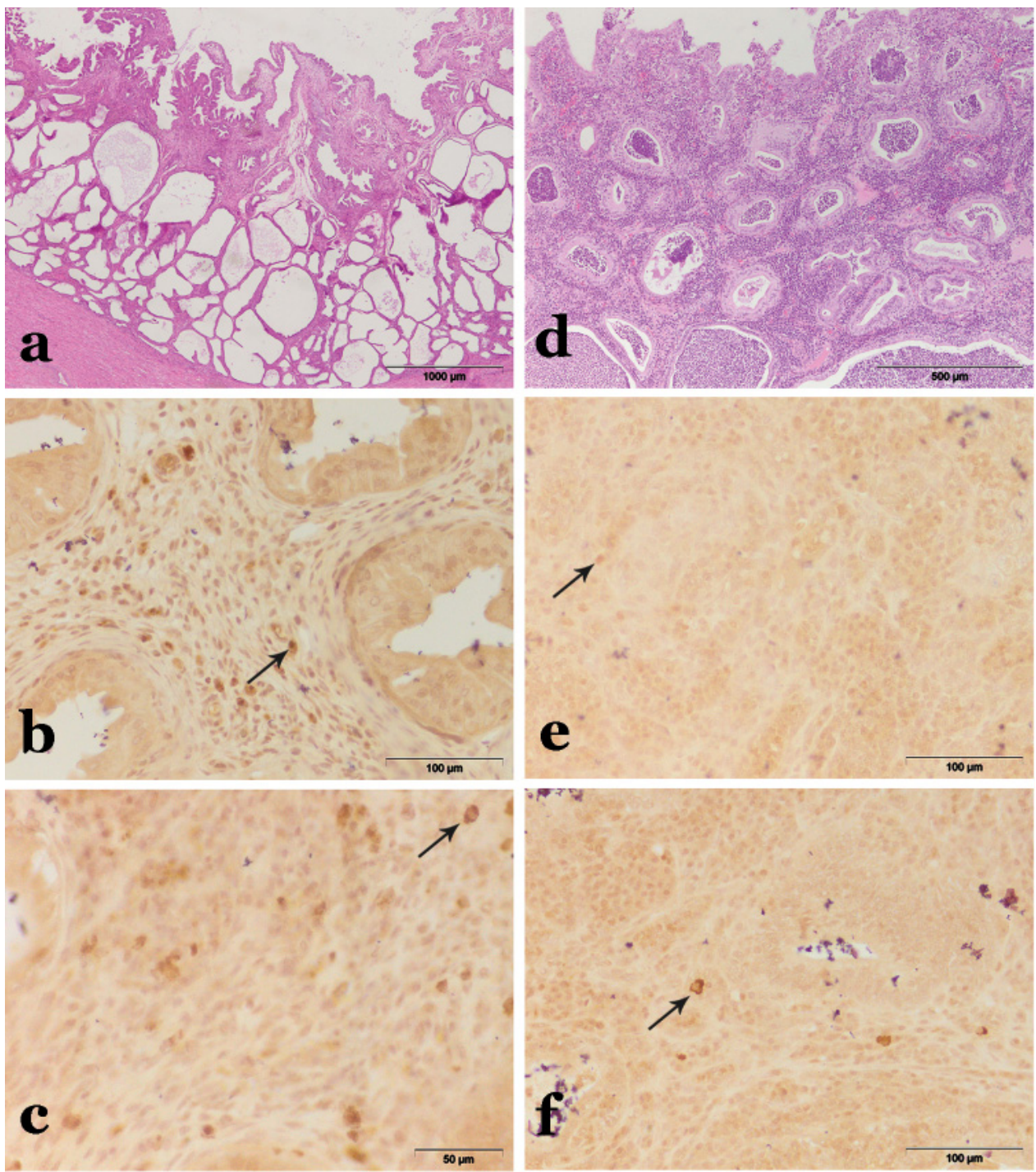

Figure 3. Histopathologic appearance of the canine endometrium, and the expression of the estrogen and progesteron receptors in $\mathrm{CEH}-\mathbf{a}) \mathrm{HE}$; b) $\mathrm{LSAB}^{+} \mathrm{ER}$ (arrow); c) $\mathrm{LSAB}^{+} \mathrm{PR}$ (arrow); and pyometra - d) HE; e) $\mathrm{LSAB}^{+} \mathrm{ER}$ (arrow); f) LSAB ${ }^{+} \mathrm{PR}$ (arrow) 


\section{DISCUSSION}

The canine estrus cycle is divided into 4 phases: proestrus, estrus, diestrus and anestrus. The uterus of the bitch, especially its epithelial layer - endometrium, show different morphological changes during the phases of the estrus cycle. These changes were particularly notable on the epithelial cells, epithelial crypts and glandular, mucus producing cells. During the proestrus the epithelial layer consisted of cuboidal cells, and crypts were also notable. Mucus producing cells were the most prominent finding. Growth, differentiation and dilatation of the glandular, mucus producing cells, as well as endometrial hyperaemia were the most prominent findings during estrus. Accumulation of the lipid droplets in the epithelial endometrial cells (FEEC - foamy endometrial epithelial cells) and well-developed mucus producing endometrial glands were the main characteristics of the diestrus phase. The anestrus phase of the estrus cycle was characterized by hardly notable crypts of the epithelium. All described changes were described by other authors $[2-4,16,17]$. Also, beside the histological changes on the endometrium, different phases of the estrus cycle were also characterized by cyclic changes of estrogen and progesterone receptor concentrations on the uterine cells which was confirmed by using an immunohistochemical technique. The anestrus phase was characterized by uterine cells - mostly stromal which showed moderate reaction of both estrogen and progesterone receptors. During proestrus uterine cells showed a weak reaction of both estrogen and progesterone receptors, in the stromal and glandular epithelial cells. During estrus a large number of uterine cells showed a strong reaction on estrogen receptors and moderate reaction on progesterone receptors. On the contrary, during diestrus the scores for the estrogen receptors decreased, while progesterone receptor level increased - uterine cells expressed highly positive (strong) reaction on the progesterone receptors, and moderate reaction on estrogen receptors. These findings were like those mentioned in the literature [5-9].

Histopathologic changes were notable both in the uterus with $\mathrm{CEH}$ and in pyometra. Cystic endometrial hyperplasia $(\mathrm{CEH})$ was characterized by a hyperplastic endometrium which formed different sized cysts in most cases without associated inflammatory cellular infiltration. On the other hand, chronic purulent endometritis - pyometra was characterized by endometrial hyperplasia, sometimes in the cystic or papilliform proliferations, enlarged prismatic endometrial cells, sometimes with pycnotic nuclei. Erosions and hemorrhages were also often noted. A dominant characteristic of pyometra was the inflammation of the endometrium which was characterized by a large number of neutrophil granulocytes, plasma cells and macrophages present in the uterine lumen, endometrium - endometrial cysts and diffusely in the epithelial and stromal part of the endometrium. Since literature data suggested that an excessive quantity of progesterone or an oversensitivity of the uterus to progesterone, due to the number of progesterone receptors, can lead to pyometra. Many authors investigated the expression of estrogen receptors alpha $(\mathrm{ER} \alpha)$ and progesterone receptors $(\mathrm{PR})$ in the bitch uterus with pyometra [8, 18-19]. Our research showed that endometrial cells in 
the uterus with $\mathrm{CEH}$ expressed astrong reaction on estrogen receptors, and a moderate reaction on progesterone receptors, but on the other hand uterine cells in uterus with pyometra expressed a moderate to strong reaction on progesterone receptors, and a weak reaction on estrogen receptors, similar to those mentioned in literature data [8,18-19]. This emphasize that when the sex steroid receptors expression of uteri from pyometra cases were compared with those of normal uteri from diestrus bitches, a lower expression level of ER in all uterine layers was observed in the pyometra cases, whereas the expression of PR in most tissue layers of canine pyometra uteri tended to be higher than in normal uteri. So, according to these findings it may be presumed that the changes of $\mathrm{ER} \alpha$ and PR expressions in the bitch uterus has its important role in the pathogenesis of pyometra [8,18-21].

\section{CONCLUSION}

The present study shows that during the phases of the canine estrus cycle different morphological changes were notable, especially on the uterine epithelial layer endometrium. Also, immunostaining of the ER and PR differed between phases of the estrus cycle, with the most strong reaction of the ER during estrus and most strong reaction of the PR during diestrus.

Also, beside characteristic changes, mostly presenton the endometrium, immunostaining of the ER and PR on uterus with $\mathrm{CEH}$ and pyometra differed, which can suggest that different factors are important of the pathogenesis of these two pathologic changes of the canine uterus.

In further research it would be interesting to perform a quantitative analysis of both estrogen and progesterone receptors during different phases of the estrus cycle and also in uterus with cystic endometrial hyperplasia and pyometra.

\section{Authors' contributions}

MD carried out histopathological and immunohistochemical examination. AM participated in histopathological and immunohistochemical examination and drafting of the manuscript. MV performed clinical investigations, surgical treatment and macroscopic examination of the tissues. VS conceived of the study, and participated in its design and coordination. NS performed vaginal cytology examination. All authors read and approved the final manuscript.

\section{Declaration of conflicting interests}

The author(s) declared no potential conflicts of interest with respect to the research, authorship, and/or publication of this article. 


\section{REFERENCES}

1. Concannon PW: Reproductive cycles of the domestic bitch. Anim Reprod Sci. 2011. 124 (3-4): 200-210

2. Sato J, Nasu M, Tsuchitani M: Comparative histopathology of the estrous or menstrual cycle in laboratory animals. J Toxicol Pathol. 2016, 29: 155-162

3. Galabova G, Egerbacher M, Aurich JE, Leitner M, Walter I: Morphological changes of the endometrial epithelium in the bitch during metoestrus and anoestrus. Reprod Domest Anim. 2003, 38(5): 415-420

4. Van Cruchten S, Van den Broeck W, D’haeseleer M, Simoens P: Proliferation patterns in the canine endometrium during the estrous cycle. Theriogenology. 2004, 62: 631-641

5. Dhaliwal GK, England GC, Noakes DE. Immunocytochemical localization of oestrogen and progesterone receptors in the uterus of the normal bitch during oestrus and metoestrus. J Reprod Fertil Suppl. 1997, 51: 167-176

6. Vermeirsch H, Simoens P, Lauwers H, Coryn M: Immunohistochemical detection of estrogen receptors in the canine uterus and their relation to sex steroid hormone levels. Theriogenology. 1999, 51(4): 729-743

7. Vermeirsch H, Simoens P, Hellemans A, Coryn M, Lauwers H: Immunohistochemical detection of progesterone receptors in the canine uterus and their relation to sex steroid hormone levels. Theriogenology. 2000, 53(3): 773-788

8. Prapaiwan N, Manee-In S, Olanratmanee E, Srisuwatanasagul S: Expression of oxytocin, progesterone, and estrogen receptors in the reproductive tract of bitches with pyometra. Theriogenology. 2017, 89:131-139

9. Vermeirsch H, Van den Broeck W, Coryn M, Simoens P: Immunohistochemical detection of androgen receptors in the canine uterus throughout the estrus cycle. Theriogenology. 2002, 57(9): 2203-2216

10. De Bosschere H, Ducatelle R, Tshamala M: Is mechanically induced cystic endometrial hyperplasia $(\mathrm{CEH})$ a suitable model for study of spontaneously occurring $\mathrm{CEH}$ in the uterus of the bitch? Reprod Domest Anim. 2002, 37(3): 152-157

11. Schlafer DH, Gifford AT: Cystic endometrial hyperplasia, pseudo-placentational endometrial hyperplasia, and other cystic conditions of the canine and feline uterus. Theriogenology. 2008, 70: 349-358

12. Arora N , Sandford J, Browning GF, Sandy JR, Wright PJ: A model for cystic endometrial hyperplasia/pyometra complex in the bitch. Theriogenology. 2006, 66: 1530-1536

13. Smith FO: Canine pyometra. Theriogenology. 2006, 66: 610-612

14. Pretzer SD: Clinical presentation of canine pyometra and mucometra: A review. Theriogenology, 2008, 70: 359-363

15. Hagman R: Canine pyometra: What is new? Reprod Dom Anim, 2017, 52 (Suppl. 2): 288292

16. Barrau MD, Abel JH Jr, Verhage HG, Tietz WR Jr: Development of the endometrium during the estrous cycle in the bitch. Am J Anat. 1975, 142(1): 47-65

17. Bartel C, Tichy A, Walter I: Characterization of foamy epithelial surface cells in the canine endometrium. Anat Histol Embryol. 2014, 43(3): 165-181

18. De Bosschere H, Ducatelle R, Tshamala M: Uterine oestrogen and progesterone receptor expression in experimental pyometra in the bitch. J Comp Pathol. 2003, 128(2-3): 99-106 
19. De Bosschere H, Ducatelle R, Vermeirsch H, Simoens P, Coryn M: Estrogen-alpha and progesterone receptor expression in cystic endometrial hyperplasia and pyometra in the bitch. Anim Reprod Sci. 2002, 70(3-4): 251-259

20. Veiga GA, Miziara RH, Angrimani DS, Papa PC, Cogliati B, Vannucchi CI: Cystic endometrial hyperplasia-pyometra syndrome in bitches: identification of hemodynamic, inflammatory, and cell proliferation changes. Biol Reprod. 2017, 96(1), 58-69

21. Derussi AA, de Souza RW, Volpato R, Guaitolini CR, Ackermann CL, Taffarel MO, Cardoso GS, Dal-Pai-Silva M, Lopes MD: Progesterone (PR), oestrogen (ER- $\alpha$ and ER$\beta)$ and oxytocin (OTR) gene expression in the oviduct and uterus of pregnant and nonpregnant bitches. Reprod Domest Anim. 201247 Suppl 6:197-199

\title{
MORFOLOŠKE KARAKTERISTIKE I EKSPRESIJA ESTROGENIH I PROGESTERONSKIH RECEPTORA NA ENDOMETRIJUMU KUJA TOKOM ESTRALNOG CIKLUSA, CISTIČNE HIPERPLAZIJE ENDOMETRIJUMA I PIOMETRE
}

\author{
MARINKOVIĆ Darko, ANIČIĆ Milan, VAKANJAC Slobodanka, \\ NEDIĆ Svetlana, MAGAŠ Vladimir
}

Estralni ciklus kuja podeljen je na četiri faze: proestrus, estrus, diestrus i anestrus, tokom kojih su prisutne kako različite morfološke promene tako i ciklične promene estrogenih i progesteronskih receptora. Nekoliko patoloških promena može se utvrditi na endometrijumu, ali svakako da su dva najznačajnija stanja - cistična hiperplazija endometrijuma i piometra u koju prethodno stanje često može da se razvije.

Cilj ovog rada je da opiše morfološke karakteristike i ekspresiju estrogenih i progesteronskih receptora na endometrijumu kuja mešanaca tokom različitih faza estralnog ciklusa, cistične hiperplazije endometrijuma i piometre.

Materice i jajnici 36 kuja mešanaca u različitim fazama estralnog ciklusa, kao i sa cističnom hiperplazijom endometrijuma $(\mathrm{CEH})$ i hroničnim gnojnim endometritisom - piometrom pregledane su makroskopski, histopatološki i imunohistohemijski za estrogene (ER) i progesteronske receptore (PR).

Tokom proestrusa materične ćelije pokazale su slebu reaktivnost i na estrogene i na progesteronske receptore, ali tokom estrusa veliki broj materičnih ćelija pokazao je izraženu reakciju na estrogene receptore i umereno izraženu reakciju na progesteronske receptore. Nasuprot tome, tokom diestrusa broj estrogenih receptora je opao dok se nivo progesteronskih receptora uvećao što je uslovilo snažnu reakciju na progesteronske receptore i umerenu reakciju na estrogene receptore.

Materične ćelije kod cistične hiperplazije endometrijuma pokazale su snažnu reakciju na estrogene receptore i umerenu reakciju na progesteronske receptore, ali s druge 
strane materične ćelije kod piometre pokazale su umerenu reaktivnost za progesteronske receptore i slabu reakciju za estrogene receptore.

Bilo bi korisno da se u narednim istraživanjima izvedu kvantitativne analize estrogenih i progesteronskih receptora tokom različitih faza estralnog ciklusa kao i na matericama sa cističnom hiperplazijom endometrijuma i piometrom. 